\title{
EFEKTIVITAS MIKROKAPSUL OLEORESIN FULI PALA (Myristica fragrans HOUTT) SEBAGAI PENGAWET DAGING AYAM BROILER
}

\section{[Effectivity of Microcapsil Mace Nutmeg(Myristica fragrans HOUTT) Oleoresin as Preservative of Boiler Chicken Meat]}

\author{
Alston Millan*, Yohanis Sirante \\ Program Studi Budidaya Tanaman Perkebuanan, Politeknik Malinau \\ *Email korespondensi: alstonmillan31@gmail.com \\ Diterima: 25 Agustus 2019 \\ Disetujui: 21 Maret 2020 \\ DOI: /10.23960/jtihp.v25i1.52-61
}

\begin{abstract}
Nutmeg oleoresin microcapsules are the solid, liquid, and gas coating technology of the nutmeg fruit. The purpose of this study was to know how mace nutmeg oleoresin microcapsules could preserve the broiler chicken meat at room temperature during 4 days of observation. The experimental design used was a Completely Randomized Design (CRD) consisting of 5 treatments with mace concentration of nutmeg microcapsules oleoresin $(0,50,100,150$, and 200) ppm. The variables observed were water content, $\mathrm{pH}$ val$u e$, total microbes, and organoleptic properties (color, aroma, and texture). The results showed that mace nutmeg oleoresin microcapsules did not affect $(p>0.05)$ water content and sensory properties of broiler chicken meat, but had a significant effect $(p<0.05)$ on the $\mathrm{pH}$ value and total microbe at the same day of room temperature storage. Panel organoleptic test results on the level of preference for meat color, aroma, and texture of chicken meat were in the range score of 3 (somewhat like) to 4 (somewhat dislike). The treatments of nutmeg oleoresin did not affect $(p>0.05)$ on color, the aroma, and the texture of broiler chicken meat. This research shows that marinating using oleoresin microcapsules has not been effective as a preservative to broiler chicken meat at room temperature.
\end{abstract}

Keywords: chicken meat, mace nutmeg oleoresin microcapsules

\begin{abstract}
ABSTRAK
Mikrokapsul oleoresin fuli pala merupakan teknologi penyalutan padatan, cairan dan gas. Tujuan penelitian ini adalah untuk mengetahui bagaimana mikrokapsul oleoresin fuli pala dapat mengawetkan daging ayam broiler pada suhu ruangan selama 4 hari. Rancangan percobaan yang digunakan adalah Rancangan Acak Lengkap (RAL) terdiri dari 5 perlakuan konsentrasi mikrokapsul fuli pala yaitu 0, 50, 100, 150, dan 200 ppm. Variabel yang diamati adalah kadar air, nilai $\mathrm{pH}$, total mikroba dan sifat organoleptik (warna, aroma dan tekstur). Hasil penelitian menunjukkan bahwa daging ayam broiler yang direndam menggunakan mikrokapsul oleoresin fuli pala tidak berpengaruh $(p>0,05)$ terhadap kadar air dan uji organoleptik (warna, aroma dan tekstur), tetapi berpengaruh nyata $(p<0,05)$ terhadap nilai $\mathrm{pH}$ dan total mikroba pada hari yang sama $(0,2$, dan 4$)$ dan disimpan pada suhu ruang. Hasil uji organoleptic panelis pada tingkat kesukaan terhadap warna daging, aroma dan tekstur daging ayam berada pada kisaran angka 3 (agak suka) sampai 4 (agak tidak suka). Penelitian ini menunjukan bahwa
\end{abstract}


mikrokapsul oleoresin fuli pala belum efektik sebagai pengawat daging broiler ayam pada suhu ruang.

Kata kunci: daging ayam, mikrokapsul oleoresin fuli pala

\section{PENDAHULUAN}

Salah satu bahan pangan yang sering dikonsumsi oleh masyarakat adalah daging ayam broiler. Daging ayam broiler banyak mengandung nutrisi seperti protein, lemak, mineral, karbohidrat dan vitamin. Kandungan nutrisi yang tinggi pada daging ayam broiler sangat baik untuk perkembangbiakan mikroorganisme yang menyebabkan kebusukan dan kerusakan. Kerusakan pada daging ditandai dengan adanya perubahan fisik dan perubahan kimia (Windiyartono et al., 2016). Menurut Soeparno (2011), pengawetan merupakan salah satu cara untuk meningkatkan daya simpan daging segar maupun produk daging olahan. Proses pengawetan pada dasar -nya memperlambat laju pertumbuhan maupun perkembangan mikroorganisme didalam daging, bisa menggunakan garam (Raharjo, 2015), gula (Evanuarini et al., 2011), atau rempah-rempah (Arrizqiyani et al., 2017) .

Penggunaan rempah-rempah sebagai pengawet alami sudah banyak digunakan untuk menghambat terjadinya kerusakan daging (Arrizqiyani et al., 2017). Salah satu bahan alami yang berfungsi sebagai bumbu, flavor dan sekaligus sebagai pengawet dalam pangan atau makanan adalah fuli pala (Myristica fragrans Houtt). Fuli pala mampu sebagai anti mikroba dan antibakteri (Rastuti et al., 2012; Agustinisari et al., 2014), antioksidan (Wijayanti et al., 2018; Wibowo et al., 2018), serta antifungi (Agaus dan Agaus, 2019).

Penggunaan fuli pala dalam bentuk utuh, irisan, bubuk dan oleoresin memiliki kelemahan seperti oleoresin tidak larut dalam air, sehingga perlu membuat mikrokapsul dari oleoserin fuli pala.

Penelitian mengenai penggunaan mikrokapsul sudah pernah dilakukan oleh
Khasanah et al. (2015), yang membuat mikrokapsul menggunakan kombinasi gum arab, maltodekstrin dan susu skim sebagai enkapsulan untuk mengetahui sifat mikrokapsul oleoresin daun kayu manis secara fisik dan kimia.

Penelitian tentang penggunaan mikrokapsul oleoresin fuli pala belum pernah dilakukan, sehingga perlu dilakukan penelitian tentang penggunaan mikrokapsul oleoresin fuli pala terhadap daging ayam broiler. Penelitian ini bertujuan untuk mengetahui bagaimana mikrokapsul oleoresin fuli pala dapat mengawetkan daging ayam broiler.

\section{BAHAN DAN METODE}

\section{Bahan dan Alat}

Bahan-bahan yang digunakan pada penelitian ini adalah daging ayam broiler bagian dada/breast sebanyak $4 \mathrm{~kg}$ yang diperoleh dari Pasar Induk Malinau dan mikrokapsul oleoresin fuli pala yang diperoleh dari hasil penelitian sebelumnya sebanyak 200 gram. Peralatan yang dipakain pada penelitian ini adalah $\mathrm{pH}$ meter, oven, desikator, cawan petri, alat-alat gelas, kertas krep, timbangan analitik, autoclave, incubator, plastik vacuum, botol sampel, lampu spritus, jarum ose, kapas, masker, sarung tangan untuk analisis total mikroba.

\section{Metode Penelitian}

Penelitian ini dilakukan mulai tanggal 01 s.d. 06 Agustus 2019 di Laboratorium UPTD Pupuk Organik Hayati Dinas Pertanian, Peternakan dan Perikanan Kabupaten Malinau, Kalimantan Utara.

Rancangan percobaan aplikasi mikrokapsul pada daging ayam broiler 
menggunakan Rancangan Acak Lengkap (RAL)dengan tiga ulangan dan lima perlakuan, yaitu $\mathrm{P} 1=$ konsentrasi mikrokapsul oleoresin fuli pala $0 \mathrm{ppm}$; $\mathrm{P} 2=$ konsentrasi mikrokapsul oleoresin fuli pala $50 \mathrm{ppm}$; P3= konsentrasi mikrokapsul oleoresin fuli pala 100 ppm; P4= konsentrasi mikrokapsul oleoresin fuli pala $150 \mathrm{ppm}$; P5= konsentrasi mikrokapsul oleoresin fuli pala $200 \mathrm{ppm}$. Analisis data dihitung menggunakan analisa statistik dan dilanjutkan dengan uji lanjutan DMRT apabila ada perbedaan antar perlakuan menggunakan aplikasi SPPS versi 23, (www.ibm.com, 2019).

Analisis dilakukan meliputi kadar air, pH, Total Plate Count (TPC), dan sifat organoleptik (warna, aroma dan tekstur) daging ayam broiler yang disimpan selama 0 hari, 2 hari, 4 hari pada suhu ruang.

\section{Prosedur/Pelaksanaan Penelitian}

Aplikasi mikrokapsul oleoresin fuli pala pada daging ayam broiler dilaksanakan menggunakan metode Wikanta et al. (2012). Penggunaan mikrokapsul oleoresin fuli pala pada daging ayam broiler dilakukan dengan cara perendaman sebelum proses penyimpanan daging. Perendaman daging ayam broiler dengan berbagai konsentrasi mikrokapsul fuli pala dilakukan selama satu jam. Adapun konsentrasi mikrokapsul fuli pala setiap perlakuan yaitu: $0 \mathrm{ppm} /$ liter, $50 \mathrm{ppm} /$ liter, $100 \mathrm{ppm} /$ liter, $150 \mathrm{ppm} /$ liter dan $200 \mathrm{ppm} /$ liter air. Daging ayam broiler yang sudah direndam lalu dikemas dengan plastik jenis low density polyethylene lalu disimpan selama 0 hari, 2 hari, 4 hari pada suhu ruang.

\section{Kadar Air (AOAC, 2005)}

Cawan aluminium kosong dipanaskan menggunakan oven pada suhu $105^{\circ} \mathrm{C}$ dalam waktu 30 menit, kemudian didinginkan dengan desikator lalu cawan aluminium diukur beratnya. Prosedur pengeringanan cawan aluminium diulang untuk memperoleh berat yang sama. Sampel daging ayam broiler sejumlah 2 gr yang sudah dikeringkan lalu ditimbang, kemudian sampel dipanaskan kedalam oven dengan suhu $105^{\circ} \mathrm{C}$ dalam waktu 6 jam. Sampel dikeluarkan lalu didinginkan dalam desikator dalam waktu 30 menit. Pengeringan sampel diulang sampai mendapatkan berat yang sama. Perhitungan persentase kadar air menggunakan rumus sebagai berikut :

$$
\text { Kadar Air }(\% b b) \frac{W 3}{W 1} \times 100
$$

Keterangan:

$\mathrm{W} 3$ = kehilangan berat

$\mathrm{W} 1$ = berat sampel

\section{Nilai pH (AOAC, 2005)}

Daging ayam broiler sebanyak 25 gr lalu ditambahkan dengan $50 \mathrm{ml}$ air destilasi, daging ayam broiler dihancurkan menggunakan blender untuk mendapatkan sampel yang homogen. Pengukuran nilai $\mathrm{pH}$ menggunakan $\mathrm{pH}$ meter. Sebelum pengukuran $\mathrm{pH}$ dilakukan, $\mathrm{pH}$ meter harus dikalibrasi menggunakan buffer $\mathrm{pH} 4$ dan 7. Setelah itu pengukuran nilai $\mathrm{pH}$ daging ayam broiler, dengan cara elektroda $\mathrm{pH}$ dicelupkan kedalam larutan daging ayam broiler sampai mendapatkan nilai yang normal.

\section{Total Mikroba (SNI: 7388:2009)}

Sampel daging ayam broiler ditimbang sebanyak 10 gram lalu dimasukkan ke dalam tabung erlenmeyer yang sudah disterilisasikan. Larutan $\mathrm{NaCl}$ ditambahkan sebanyak $90 \mathrm{ml}$ ke dalam tabung erlenmeyer lalu diaduk sampai homogen. Sampel diambil sebanyak $1 \mathrm{ml}$ dari tabung erlenmeyer menggunakan pipet dan dimasukkan kedalam tabung reaksi 1 lalu diaduk sampai homogen. Sampel tersebut kemudian diambil sebanyak $1 \mathrm{ml}$ dan dimasukan ke dalam tabung reaksi 2, diaduk sampai homogen. Proses yang sama dari tabung reaksi ke 2, ke 3 dan seterusnya sampai tabung reaksi ke enam. Masing- 
masing tabung reaksi diambil sampel sebanyak $1 \mathrm{ml}$ dan kemudian dimasukkan kedalam cawan petri steril, lalu ditambahkan dengan agar cair sebanyak $10 \mathrm{ml}-15$ ml. Cawan petri yang berisi sampel akan membeku pada suhu ruangan, kemudian diinkubasi dengan suhu $37^{\circ} \mathrm{C}$ selama $24-48$ jam pada posisi terbalik. Setelah jumlah koloni bakterinya terbentuk kemudian dihitung dengan menggunakan rumus pada Tabel 1.

Tabel 1. Rumus perhitungan jumlah koloni

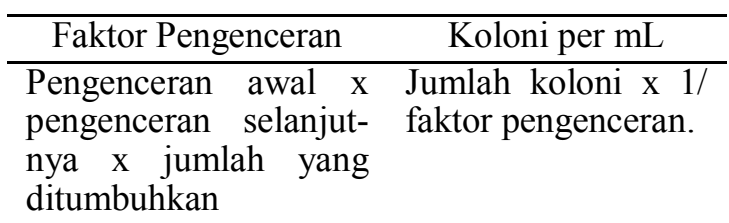

\section{Uji Organoleptik}

Uji perbedaan secara organoleptik terhadap warna, aroma, dan tekstur pada daging ayam didasarkan pada skala perbandingan yang ditransformasikan menjadi skala numerik (Tabel 2).

Tabel 2. Pengujian organoleptik menggunakan skala perbandingan dan skala numerik warna, aroma, dan tekstur.

\begin{tabular}{cc}
\hline Skala Perbandingan & Skala Numerik \\
\hline Sangat Suka & 1 \\
Suka & 2 \\
Agak Suka & 3 \\
Agak Tidak Suka & 4 \\
Tidak Suka & 5 \\
Sangat Tidak Suka & 6 \\
\hline
\end{tabular}

Sumber : (Marlina, 2012)
Pengujian organoleptik pada panelis dilakukan dengan cara menyajikan 5 sampel daging ayam masing-masing satu potong daging yang telah diberi kode MKOF30 (P1), MKOF32 (P2), MKOF34 (P3), MKOF34 (P4), MKOF36 (P5). Pengujian organoleptik menggunakan panelis agak terlatih sebanyak 15 orang sebagi ulangan.

\section{HASIL DAN PEMBAHASAN}

\section{Kadar Air}

Hasil uji Duncan menunjukkan bahwa penggunaan lima perlakuan konsentrasi mikrokapsul oleoresin fuli pala tidak berpengaruh nyata pada kadar air daging ayam boiler yang diamati pada penyimpanan 0, 2 dan 4 hari (Tabel 3). Penggunaan plastik low density sebagai media penyimpanan daging boiler dalam penelitian ini tidak berpangaruh terhadap kadar air daging ayam boiler. Hal ini diduga karena degradasi kolagen dari protein daging ayam yang menyusun ikatan silang diantara serat daging berfungsi menahan air daging (Hartati, 2012). Selain itu, aplikasi mikrokapsul bergantung pada bahan yang digunakan dalam proses pembuatan mikrokapsul (Balasubramani et al., 2014; Khasanah et al., 2015). Kadar air daging ayam pada masing-masing perlakuan penggunaan mikrokapsul oleoresin fuli pala mempunyai rentang penurunan sebagai berikut pada konsentrasi 0 ppm dari $23,96 \%$ menjadi $20,30 \%$; pada konsentrasi 50 ppm dari $24,76 \%$ menjadi $20,16 \%$; pada

Tabel 3. Nilai kadar air

\begin{tabular}{cccc}
\hline $\begin{array}{c}\text { Konsentrasi Mikrokapsul } \\
\text { Oloeresin Fuli Pala }\end{array}$ & \multicolumn{3}{c}{ Lama Penyimpanan } \\
\cline { 2 - 4 } & 0 Hari & 2 Hari & 4 Hari \\
\hline 0 ppm & $23,96 \pm 0,865^{\mathrm{a}}$ & $23,48 \pm 1,563^{\mathrm{a}}$ & $20,30 \pm 0,730^{\mathrm{a}}$ \\
$50 \mathrm{ppm}$ & $24,76 \pm 0,512^{\mathrm{a}}$ & $25,93 \pm 4,839^{\mathrm{a}}$ & $20,16 \pm 1,566^{\mathrm{a}}$ \\
$100 \mathrm{ppm}$ & $23,98 \pm 0,455^{\mathrm{a}}$ & $24,47 \pm 1,129^{\mathrm{a}}$ & $21,18 \pm 2,719^{\mathrm{a}}$ \\
$150 \mathrm{ppm}$ & $23,96 \pm 0,664^{\mathrm{a}}$ & $23,61 \pm 0,288^{\mathrm{a}}$ & $22,05 \pm 2,129^{\mathrm{a}}$ \\
$200 \mathrm{ppm}$ & $24,81 \pm 0,628^{\mathrm{a}}$ & $23,36 \pm 1,050^{\mathrm{a}}$ & $19,54 \pm 2,078^{\mathrm{a}}$ \\
\hline
\end{tabular}

Keterangan: superskrip yang sama pada kolom menunjukkan tidak ada perbedaan yang nyata $(p>0,05)$. 
Tabel 4. Nilai $\mathrm{pH}$

\begin{tabular}{cccc}
\hline \multirow{2}{*}{$\begin{array}{c}\text { Konsentrasi Mikrokapsul } \\
\text { Oloeresin Fuli Pala }\end{array}$} & 0 Hari & 2 Hari & 4 Hari \\
\cline { 2 - 4 } & $5,5 \pm 0,000^{\mathrm{a}}$ & $6,7 \pm 0,500^{\mathrm{a}}$ & $8,0 \pm 0,000^{\mathrm{a}}$ \\
\hline $0 \mathrm{ppm}$ & $5,1 \pm 0,288^{\mathrm{ab}}$ & $7,3 \pm 0,577^{\mathrm{ab}}$ & $8,0 \pm 0,000^{\mathrm{a}}$ \\
$50 \mathrm{ppm}$ & $5,3 \pm 0,577^{\mathrm{ab}}$ & $7,3 \pm 0,577^{\mathrm{ab}}$ & $8,0 \pm 0,000^{\mathrm{a}}$ \\
$100 \mathrm{ppm}$ & $5,0 \pm 0,000^{\mathrm{ab}}$ & $7,6 \pm 0,577^{\mathrm{b}}$ & $7,6 \pm 0,577^{\mathrm{a}}$ \\
$150 \mathrm{ppm}$ & $5,6 \pm 0,288^{\mathrm{b}}$ & $7,6 \pm 0,577^{\mathrm{b}}$ & $7,3 \pm 0,577^{\mathrm{a}}$ \\
\hline
\end{tabular}

Keterangan: superskrip yang berbeda dalam kolom yang sama menunjukkan perbedaan yang nyata ( $p>$ $0,05)$

konsentrasi 100 ppm dari 23,98\% menjadi 21,18\%; pada konsentrasi 150 ppm dari $23,96 \%$ menjadi $22,05 \%$; pada konsentrasi 200 ppm dari 24,81\% menjadi 19,54\%. Jadi penurunan kadar air daging ayam boiler bukan karena penggunaan mikrokapsul oleoresin fuli pala dalam perendaman akan tetapi karena faktor penyimpanan.

\section{Nilai pH}

Nilai $\mathrm{pH}$ daging ayam broiler yang direndam menggunakan mikrokapsul oleoresin fuli pala yang disimpan pada suhu ruangan dapat dilihat pada Tabel 4. Nilai $\mathrm{pH}$ merupakan faktor penting dalam menentukan kualitas daging baik secara fisik maupun mikrobiologis sehingga sangat menentukan tingkat keawetan dan kualitasnya.

Tabel 4. Menunjukkan bahwa perendaman menggunakan mikrokapsul oleoresin fuli pala daging ayam broiler menunjukkan perbedaan yang nyata pada konsentrasi 0 ppm dan 200 ppm Hasil penelitian menunjukkan bahwa terjadi peningkatan nilai $\mathrm{pH}$ pada daging ayam yang sudah direndam dengan mikrokapsul oleoresin fuli pala. Menurut Arizona et al. (2011), Ginting et al. (2014) dan Koswara et al. (2011) bahwa nilai $\mathrm{pH}$ daging yang semakin tinggi disebabkan oleh mikroba yang mendominasi asam-asam amino dalam daging sehingga menghasilkan senyawa-senyawa bersifat basa.

Kisaran $\mathrm{pH}$ daging ayam broiler yang direndam menggunakan mikrokapsul oleoresin fuli pala antara 5,00-8,00 hingga hari ke-4. Nilai $\mathrm{pH}$ ini lebih tinggi bila dibandingkan dengan penelitian Jaelani et al. (2014) yang memiliki $\mathrm{pH}$ rata-rata sebesar 5,95 dan hasil penelitian Pura et al. (2015) dimana $\mathrm{pH}$ daging ayam broiler tanpa perlakuan apapun adalah 5,75 - 5,97 serta hasil penelitian Afrianti et al. (2013) dimana daging ayam broiler tanpa perlakuan apapun memiliki $\mathrm{pH}$ rata-rata 6,79 dalam rentang masa simpan $6-12$ jam.

\section{Nilai TPC Daging Ayam Broiler}

Nilai total mikroba daging ayam broiler yang direndam menggunakan mikrokapsul oleoresin fuli pala pada suhu ruang (cfu/g) dapat dilihat pada Tabel 5. yang menunjukkan bertambahnyaa waktu penyimpanan menyebabkan peningkatan total mikroba dalam daging. Hal ini sejalan dengan penelitian Ginting et al. (2014) bahwa dengan bertambahnya waktu penyimpanan maka total mikroba pun akan semakin meningkat

Hasil penelitian menunjukkan bahwa nilai total mikroba daging ayam berbeda-beda pada setiap konsentrasi yang dicobakan. Nilai tertinggi diperoleh perlakuan konsentrasi 200 ppm pada penyimpanan 4 hari dengan nilai $3,59 \times 1010$ koloni/g dan nilai terendah diperoleh konsentrasi $150 \mathrm{ppm}$ pada penyimpanan 0 hari dengan nilai 2,40x107 koloni/g (Tabel 5). Secara umum perlakuan oleoresin belum 
Tabel 5. Nilai Total Mikroba (cfu/g)

\begin{tabular}{cccc}
\hline $\begin{array}{c}\text { Konsentrasi } \\
\text { Mikrokapsul } \\
\text { Oloeresin Fuli Pala }\end{array}$ & 0 Hari & 2 Hari & 4 Hari \\
\cline { 2 - 4 } & $7,27 \times 10^{7 \mathrm{a}}$ & $4,94 \times 10^{8 \mathrm{a}}$ & $1,03 \times 10^{10 \mathrm{a}}$ \\
$50 \mathrm{ppm}$ & $7,67 \times 10^{7 \mathrm{a}}$ & $6,13 \times 10^{8 \mathrm{a}}$ & $2,04 \times 10^{10 \mathrm{a}}$ \\
$100 \mathrm{ppm}$ & $5,07 \times 10^{7 \mathrm{a}}$ & $6,65 \times 10^{8 \mathrm{a}}$ & $2,67 \times 10^{9 \mathrm{~b}}$ \\
$150 \mathrm{ppm}$ & $2,40 \times 10^{7 \mathrm{a}}$ & $4,87 \times 10^{8 \mathrm{a}}$ & $3,31 \times 10^{10 \mathrm{c}}$ \\
$200 \mathrm{ppm}$ & $1,62 \times 10^{8 \mathrm{~b}}$ & $5,16 \times 10^{8 \mathrm{a}}$ & $3,59 \times 10^{10 \mathrm{c}}$ \\
\hline
\end{tabular}

Keterangan: superskrip yang berbeda dalam kolom sama menunjukkan perbedaan yang nyata $(p<0,05)$

mampu menekan jumlah total mikroba sehingga pada hari ke empat telah mencapai $1010 \mathrm{koloni} / \mathrm{g}$. Nilai total mikroba daging ayam yang direndam menggunakan mikrokapsul oleoresin fuli pala pada semua perlakuan menunjukkan total mikroba semakin meningkat dengan bertambahnya masa simpan daging ayam broiler pada suhu ruang, Hal ini dapat disebabkan karena daging broiler telah mengandung jumlah mikroba awal yang tinggi sehingga aplikasi oleoresin sebagai pengawet alami menjadi tidak efektif.

Tingginya jumlah mikroba awal didalam daging ayam disebabkan oleh berbagai faktor eksternal seperti tingkat kebersihan rumah pemotongan hewan dan sanitasi peralatan. Menurut Sukmawati et al. (2018) faktor kebersihan rumah potong hewan dan sanitasi sangat mempengaruhi perkembangan cemaran mikroba pada daging ayam. Selain kebersihan rumah potong, kondisi penjualan, meja penjualan dan tempat pemotongan yang kurang higienis dapat menyebabkan daging ayam terkontaminasi oleh mikroorganisme baik yang bersifat patogen maupun nonpathogen (Hajrawati et al., 2016)

Selain itu tingginya koloni mikroba awal sampel juga dapat dipengaruhi oleh suhu dan kelembapan, baik pada waktu penyimpanan maupun pada proses distribusinya. Menurut Mukti et al. (2017) peningkatan jumlah mikroba juga dipengaruhi oleh proses pengangkutan yang masih sederhana, kurang higinis dan penggunaan transportasi yang tidak layak serta air yang digunakan selama proses pemotongan hingga pengolahan daging ayam.

Suhu merupakan salah satu faktor penting dalam perkembangan mikroba, suhu normal atau suhu ruang adalah suhu yang paling baik untuk perkembangan mikroorganisme. Demikian halnya dengan faktor kelembaban, dimana tingkat kelembaban suatu lingkungan berbanding lurus dengan tingkat kecepatan tumbuh mikroorganisme. Menurut Irawati et al. (2014), daya tembus oksigen dapat dipengaruhi oleh kemasan plastik yang digunakan untuk penyimpanan pada suhu ruang seperti plastik jenis PE. Plastik jenis PP menurut Furqon et al. (2016), lebih baik dalam mempertahankan kadar air karena memiliki permeabilitas uap air yang rendah dari pada PE.

Tempat penyimpanan daging yang higienis, tertutup dari udara bebas, serta pengaturan tingkat suhu dan kelembaban dapat mencegah dan mengurangi potensi kontaminasi mikroorganisme.

Hasil penelitian diatas menunjukan bahwa konsentrasi 100 ppm pada masa simpan 4 hari total mikroba lebih rendah dibandingkan dengan konsentrasi 0 ppm dan 50 ppm dan 200 ppm dihari yang sama dan pada konsentrasi 150 ppm masa simpan 2 hari juga menunjukkan total mikroba lebih rendah dibandingkan dengan konsentrasi lainnya. Perendaman daging ayam 
broiler menggunakan mikrokapsul oleoresin fuli pala dapat menghambat aktivitas mikroba dalam daging ayam broiler. Menurut beberapa penelitian yang mengatakan bahwa fuli pala mampu sebagai anti mikroba dan anti bakteri (Rastuti et al, 2012; Agustinisari et al., 2014), antioksidan (Wijayanti et al., 2018; Wibowo et al, 2018 ), antifungi (Agaus dan Agaus, 2019). Fuli pala mengandung senyawa aktif yaitu sabinene hexane, myristicin, phenol dan metil eugenol sehingga mampu dalam menghambat aktivitas mikroba (Arrizqiyani et al., 2017). Kandungan senyawa flavanoid pada fuli pala berperan dengan cara mengganggu perkembangan transpeptidase peptidoglikan yang menye-babkan terganggunya proses pembentukan membran sel sehingga membran sel tidak terbentuk ataupun terbentuk tetapi tidak sempurna (Rini et al., 2018).

Batas maksimum cemaran mikroba pada daging ayam menurut SNI 7388 tahun 2009 yaitu 1 x $10^{5} \mathrm{koloni} / \mathrm{g}$. Semua perlakukan yang dicobakan masih diatas batas maksimum SNI 7833 tahun 2009 maka daging ayam broiler yang disimpan pada suhu ruangan tidak bisa untuk dikonsumsi.

\section{Uji Organoleptik}

\section{Warna Daging}

Hasil pengamatan menunjukkan bahwa konsentrasi mikrokapsul oleoresin fuli pala tidak berpengaruh nyata $(p>0.05)$ terhadap warna daging ayam broiler (Tabel 6). Data menunjukkan tingkat kesukaan panelis terhadap warna daging berada pada kisaran angka 3 (agak suka) sampai 4 (agak tidak suka). Warna daging unggas sangat dipengaruhi oleh beberapa faktor seperti umur ternak, bangsa, $\mathrm{pH}$ dan pakan (Jaelani et al., 2014).

\section{Aroma Daging}

Data hasil pengamatan menunjukan bahwa perendaman daging ayam menggunakan mikrokapsul oleoresin fuli pala tidak memberikan pengaruh nyata $(p>0.05)$ terhadap aroma daging (Tabel 6). Penilaian panelis terhadap tingkat kesu-kaan aroma daging berada pada kisaran angka 3 (agak suka) sampai 4 (agak tidak suka). Kandungan lemak yang banyak pada daging ayam memberikan aroma amis yang khas. Pada penelitian ini, uji organoleptik dilakukan hanya menggunakan indra penciuman.

\section{Tekstur Daging}

Data hasil pengamatan pada menunjukkan bahwa perendaman daging ayam menggunakan mikrokapsul oleoresin fuli pala tidak memberikan pengaruh yang nyata $(p>0.05)$ terhadap tekstur daging ayam broiler (Tabel 6). Penilaian panelis terhadap tingkat kesukaan tekstur daging berada pada kisaran angka 3 (agak suka) sampai 4 (agak tidak suka). Tekstur daging ayam dipengaruhi oleh beberapa faktor an-

Tabel 6. Uji Organoleptik (Warna, Aroma dan Tekstur)

\begin{tabular}{cccc}
\hline $\begin{array}{c}\text { Konsentrasi Mikrokapsul Oleoresin } \\
\text { Fuli Pala }\end{array}$ & Warna & Tekstur & Aroma \\
\hline $0 \mathrm{ppm}$ & $3,89 \pm 1,588^{\mathrm{a}}$ & $3,84 \pm 1,613^{\mathrm{a}}$ & $3,98 \pm 0,473^{\mathrm{a}}$ \\
$50 \mathrm{ppm}$ & $3,93 \pm 1,514^{\mathrm{a}}$ & $3,60 \pm 1,424^{\mathrm{a}}$ & $3,98 \pm 0,494^{\mathrm{a}}$ \\
$100 \mathrm{ppm}$ & $3,89 \pm 1,806^{\mathrm{a}}$ & $3,36 \pm 1,230^{\mathrm{a}}$ & $3,98 \pm 0,562^{\mathrm{a}}$ \\
$150 \mathrm{ppm}$ & $3,89 \pm 1,645^{\mathrm{a}}$ & $3,71 \pm 1,543^{\mathrm{a}}$ & $4,00 \pm 0,529^{\mathrm{a}}$ \\
$200 \mathrm{ppm}$ & $3,96 \pm 1,695^{\mathrm{a}}$ & $3,64 \pm 1,426^{\mathrm{a}}$ & $4,00 \pm 0,588^{\mathrm{a}}$ \\
\hline
\end{tabular}

Keterangan : superskrip yang sama pada kolom yang sama menunjukkan tidak ada perbedaan yang nyata $(p>0,05)$ 
tara lain, umur ternak, bangsa, $\mathrm{pH}$, pakan dan lama penyimpanan (Jaelani et al., 2014).

\section{KESIMPULAN}

Hasil penelitian menunjukkan bahwa perendaman daging ayam menggunakan mikrokapsul oleoresin fuli pala mempengaruhi nilai kadar air dan mampu menurunkan nilai $\mathrm{pH}$ serta mampu mengahambat aktivitas mikroba. Total mikroba yang dihasilkan masih berada diatas batas maksimum sehingga daging ayam broiler yang disimpan pada suhu ruang tidak layak untuk dikonsumsi. Tingkat kesukaan panelis tidak berpengaruh terhadap warna daging, aroma daging dan tekstur daging ayam broiler.

\section{DAFTAR PUSTAKA}

Afrianti, M., B. Dwiloka, dan B. E. Setiani. 2013. Total bakteri, $\mathrm{pH}$ dan kadar air daging ayam broiler setelah direndam dengan ekstrak daun senduduk (Malestona malabathricum L.) selama masa simpan. Jurnal Pangan dan Gizi. 4(7):49-56.

Agaus, L. R., dan R. V. Agaus. 2019. Manfaat kesehatan tanaman pala (Myristica fragrans). Medula. 6: 662666

Agustinisari, I., E. Y. Purwani, N. Harimurti dan S. Yuliani. 2014. Aktivitas antimikroba nanoemulsi minyak biji pala. Journal Penelitian Pasca Panen. 11(1):1-8.

AOAC. 2005. Official method of analysis of the association of official analitycal chemist. benyamin franklin station. Washington D.C.

Arizona, R., E. Suryanto dan Y. Erwanto. 2011. Pengaruh konsentrasi asap cair tempurung kenari dan lama penyimpanan terhadap kualitas kimia dan fisik daging. Buletin Peternakan. 35:50-56.

Arrizqiyani, T., N. Sonjaya dan A. Asty. 2017. Optimalisasi potensi tanaman pala sebagai antibakteri escherichia coli menggunakan metode ekstraksi. Prosiding Seminar Nasional Publikasi Hasil-Hasil Penelitian dan Pengabdian Masyarakat. Oktober 2017. Semarang.

Balasubramani, P., P.T. Palaniswamy, R. Visvanathan, V. Thirupathi, A. Subbayaran, dan J.P. Maran, 2014. Microencapsulation of garlic oleoresin using maltodextrin as wall material by spray drying technology. International Journal of Biological Macromolecules. 72: 210-217.

BSN. 2009. SNI: 7388:2009 Tentang Batas Maksimum Cemaran Mikroba Dalam Bahan Makanan Asal Hewan. Badan Standarisasi Nasional. Jakarta.

Evanuarini dan H. Huda. 2011. Kualitas dendeng sapi giling pada penambahan gula yang berbeda. Jurnal Ilmuilmu Peternakan. 21(2):7 - 10.

Furqon, A. A. Q., I. Maflahah dan A. Rahman. 2016. Pengaruh jenis pengemas dan lama penyimpanan terhadap mutu produk nugget gembus. Jurnal Agrointek. 10(2):70-74.

Ginting, C., S. Ginting, dan I. Suhaidi. 2014. Pengaruh jumlah bubuk kunyit terhadap mutu tahu segar selama penyimpanan pada suhu ruang. Jutnal Rekayasa Pangan dan Pertanian. 2 (4): 52-60.

Hajrawati, M., Fadliah, Wahyuni dan I. I. Arief. 2016. Kualitas fisik, mikrobiologis, dan organoleptik daging ayam broiler pada pasar tradisional. Jurnal Ilmu Produksi. 4(3):386-389.

Hartati, S. 2012. Populasi Mikroba dan Sifat Fisik Daging Sapi Beku Selama 
Penyimpanan. (Skripsi). Fakultas Agroindustri. Universitas Mercu Buana. Yogyakarta.

https://www.ibm.com/support/pages/ downloading-ibm-spss-statistics-23. (diunduh pada tanggal 24 Agustus 2019).

Irawati, N., dan Y. Hanurawaty. 2014. Penggunaan kemesan plastik jenis PE (polythylen), PP (polypropylen) dan plastik wrap terhadap angka kuman pada daging ayam. Jurnal Kesehatan. 13(1):21-28.

Jaelani, A., S. Dharmawati dan Wanda. 2014. Berbagai lama penyimpanan daging ayam broiler segar dalam kemasan plastik pada lemari es (Suhu $4^{0} \mathrm{C}$ ) dan pengaruhnya terhadap sifat fisik dan organoleptik. Ziraa'ah Majalah Ilmiah Pertanian. 39(3):119128.

Khasanah, L. U., B. K. Anandhito, T. Rachmawaty, R. Utami, dan G. J. Manuhara. 2015. Pengaruh rasio bahan penyalut maltodekstrin, gum ar$\mathrm{ab}$, dan susu skim terhadap karakteristik fisik dan kimia mikrokapsul oleoresin daun kayu manis (Cinnamomum burmannii). Jurnal Agritech. 35(4): 414-421.

Koswara dan Sutrisno. 2011. Nilai Gizi, Pengawetan dan Pengolahan Tahu. Produksi : eBook Pangan.

Marlina, E. T., R. L. Balia dan Y. A. Hidayati. 2012. Uji organoleptik yang diberi ransum yang mengandung lumpur susu terfermentasi oleh Aspergillus niger. Jurnal Ilmu Ternak. 12(1): 21-28.

Mukti, A., Rastina, A. Harris, Ismail, Darniati dan D. Masyitha. 2017. Resistensi Escherichia Coli terhadap antibiotik dari daging ayam broiler di pasar rukoh. Jurnal Ilmiah Mahasiswa Veteriner. 1(3): 492-498.
Pura, E. A., K. Suradi dan L. Suryaningsih. 2015. pengaruh berbagai konsentrasi daun salam (syzygiumpolyanthum) terhadap daya awet dan akseptabilitas pada karkas ayam broiler. Jurnal Ilmu Ternak. 15(2):32-38.

Puspitasari, I., A. M. P. Nuhriawangsa, dan W. Swastike. 2013. Pengaruh pemanfaatan kunyit (Curcuma domestica val.) terhadap kualitas mikrobia dan fisiko-kimia daging sapi. Tropical Animal Husbandry Journal. 2(1):5864.

Rastuti, U., S. Widyaningsih, D. Kartika, dan D. R. Ningsih. 2013. Aktivitas antibakteri minyak atsiri daun pala dari banyumas terhadap Staphylococcus aureus dan Escherichia coli serta identifikasi senyawa penyusunnya. Molekul. 8 (2): 197-203.

Raharjo, D. 2015. Daya Tahan Ikan Bandeng Segar yang Diawetkan Menggunakan Pengawet Alami Kombinasi Daun Jambu Mete (Anacardium occidentale) dan Garam. (Skripsi). Universitas Muhammadiyah Surakarta. Surakarta.

Rini, C. S., Rohmah, dan L. Y. Widyaningrum. 2018. Efektivitas Kunyit (Curcuma longa Linn) terhadap Esherichia coli dan Bacillus subtilis. Journal of Medical Laboratory Science/Technology. 1(1):1-6.

Soeparno. 2011. Ilmu nutrisi gizi dan daging. Jojgakarta : Gadjah Mada University Press. Hal 30.

Sukmawati. 2018. Total microbial plates on beef and beef offal. Journal BioScience. 2(1):22-28.

Wibowo, D. P., Y. Febriani., H. D. Riasari, dan L. Aulifa. 2018. Komposisi minyak atsiri, uji aktivitas antioksidan dan antibakteri biji pala (Myristica fragrans Houtt.) dari Garut Jawa 
Barat. Jurnal Sains dan Teknologi Farmasi Indonesia. 5 (3) : 82-87.

Wijayanti, P. A., B. Kunarto, E. Pratiwi dan Rohadi. 2018. Total fenolik, flavonoid, antosianin dan aktivitas antioksidan oleoresin fuli pala (Myristica Fragrans Houtt) yang diekstrak menggunakan metode solid liquid microwave assisted extraction. Jurnal Teknologi Pangan dan Hasil Pertanian. 13(1):1-9.

Wikanta, D. K., M. T. Susanti, F. Arifan dan H. Suyanto. 2012. Kemampuan asap cair pada pengawetan ikan bandeng (Chanos Chanos Forsk) disertai perendaman prapengasapan dalam larutan mikrokapsul oleoresin daun sirih (Piper betle L.). Prosiding Seminar Nasional Kimia III. Himpunan Kimia Indonesia. Maret 2012. Semarang.

Windiyartono, A., R. Riyantib, dan V. Wanniatie. 2016. Efektivitas tepung bunga kecombrang (nicolaia speciosa horan) sebagai pengawet terhadap aspek kimia daging ayam broiler. Jurnal Ilmiah Peternakan Terpadu. 4(1):19-23. 